\title{
PENGELOMPOKAN PROVINSI DI INDONESIA BERDASARKAN INDIKATOR MUTU PENDIDIKAN SEKOLAH MENENGAH PERTAMA TAHUN 2016-2018 MENGGUNAKAN MODEL BASED CLUSTERING
}

\author{
Uly Aldini ${ }^{(1)}$, Wara Pramesti ${ }^{(2)}$ \\ Universitas PGRI Adi Buana Surabaya \\ Jl. Dukuh Menanggal XII Telp. (031)8289873, Surabaya 60234 \\ e-mail: dinialdini30@gmail.com,warapra@unipasby.ac.id
}

\begin{abstract}
ABSTRAK
Peran pendidikan dalam suatu bangsa bertujuan untuk membentuk sumber daya manusia yang terdidik, berkompeten dan berkarakter. Standar Nasional Pendidikan (SNP) ditetapkan sebagai acuan pengukuran mutu pendidikan di Indonesia, dengan melihat delapan aspek yaitu Standar Pendidikan dan Tenaga Kependidikan, Standar Sarana dan Prasarana, Standar Pengelolaan, Standar Pembiayaan Pendidikan, Standar Isi, Standar Proses, Standar Penilaian Pendidikan dan Standar Kompetensi Lulusan. Penelitian sebelumnya mengenai faktor dominan yang membentuk mutu pendidikan jenjang sekolah dasar dan menengah, menjelaskan bahwa terdapat lebih dari 50 indikator yang memuat data multivariat. Melalui indikator - indikator tersebut, penulis ingin mengukur mutu pendidikan dengan mengelompokan provinsi di Indonesia menggunakan metode Model Based Clustering. Metode ini sangat sesuai dengan data yang terindikasi kasus outlier, dengan pendekatan menggunakan jarak Mahalanobis dan jarak Robust akan diketahui di titik mana data tersebut mengalami outlier. Data yang terindikasi outlier menyebabkan tidak terpenuhinya asumsi normal multivariat, sehingga distribusi probabilitas yang sesuai adalah distribusi $t$ multivariat. Penaksiran parameter menggunakan Maximum Likelihood Estimation terhadap Model Finite Mixture dengan $t$ multivariat dipandang sebagai metode yang lebih robust terhadap data yang mengandung outlier. Model terbaik dari kelompok yang terbentuk akan dilihat melalui perhitungan ICL tertinggi.
\end{abstract}

Kata kunci : SNP, Maximum Likelihood Estimator, Model Based Clustering.

\begin{abstract}
The role of education in a nation aims to shape educated, competent and characterized human resources. National Education Standards (SNP) are set as a reference for the education quality in Indonesia through eight aspects, which are Education and Education Staff Standards, Facilities and Infrastructure Standards, Management Standards, Education Financing Standards, Content Standards, Process Standards, Education Assessment Standards and Graduates Competency Standards. Prior research about the dominant factors which shape the education quality in primary and secondary school levels explains that there are more than 50 indicators containing multivariate data. Through these indicators, the author wants to measure the education quality by grouping provinces in Indonesia using the Model Based Clustering method. This method is appropriate with the data which is indicated as outlier cases, with the approach involving the Mahalanobis distance and the Robust distance, the point where the data is experiencing the outlier will be found. The outlier data causes the multivariate normal assumptions to be unfulfilled, so the corresponding probability distribution is the multivariate t-distribution. Parameter estimation using Maximum Likelihood Estimation of Finite Mixture Model with multivariate $t$ is seen as a more robust method for data containing outliers. The best model of the group formed will be seen through the highest ICL calculation.
\end{abstract}

Keywords: SNP, Maximum Likelihood Estimator, Model Based Clustering

Uly Aldini ${ }^{1}$, Wara Pramesti ${ }^{2}$ / J Statistika Vol 13, No 2, (2020) 


\section{PENDAHULUAN}

Pendidikan adalah usaha dasar dan terencana untuk mewujudkan suasana belajar dan proses pembelajaran agar peserta didik secara aktif mengembangkan potensi dirinya untuk memiliki kekuatan spriritual keagamaan, pengendalian diri, kepribadian, kecerdasan, akhlak mulia, serta keterampilan, yang diperlukan dirinya, masyarakat, dan negara (UU Sisdiknas No. 20 Tahun 2003). Terdapat tiga faktor yang menentukan proses keberhasilan dalam pendidikan yaitu: 1. faktor masukan (raw input); yakni peserta didik yang mengikuti proses belajar mengajar, 2. Faktor lingkungan (Environmental Input); yakni faktor yang berasal dari luar lingkungan sekolah atau proses belajar mengajar seperti: keluarga dan masyarakat, 3. Faktor instrumental input; yakni kebijakan pendidikan, kurikulum, pendidik, serta sarana dan fasilitas. Ketiga faktor tersebut nantinya mengalami proses transformasi pendidikan yang kemudian menghasilkan output berupa lulusan (Satmoko, 1996).

Global Education Monitoring Report (2016) menempatkan Indonesia pada urutan ke 10 dari 14 negara berkembang mengenai kualitas pendidikan. Kuantitas guru mengalami peningkatan sebanyak $382 \%$ atau sebanyak 3 juta orang, dan di antaranya masih terdapat $25 \%$ guru yang belum memenuhi syarat kualifikasi akademik, serta $52 \%$ belum memiliki sertifikasi profesi. Meski demikian kualitas para pendidik Indonesia masih menempati urutan ke - 14 dari 14 negara berkembang di dunia. Selain itu, survei Programme for Internatioal Student Assestment (PISA) pada 2015 memposisikan Indonesia berada di urutan ke - 64 dari 72 negara. Kemampuan memahami dan keterampilan menggunakan bahan - bahan bacaan, khususnya teks dokumen pada anak - anak Indonesia usia 9 - 14 tahun berada di peringkat sepuluh terbawah di dunia.

Kondisi yang demikian menjelaskan bahwa kualitas pendidikan Indonesia khususnya pada jenjang pendidikan dasar masih tergolong rendah. Pendidikan dasar merupakan jenjang pendidikan yang melandasi jenjang pendidikan menengah. Pendidikan dasar terbentuk dari Sekolah Dasar (SD) dan Sekolah Menengah Pertama (SMP) sebagai tingkat yang lebih tinggi, sehingga pengklasifikasian mengenai mutu pendidikan pada jenjang Sekolah Menengah Pertama (SMP) di Indonesia menjadi topik utama dalam penelitian ini. Wilayah (provinsi) dikelompokan berdasarkan indikator Standar Nasional Pendidikan (SNP). Pemerintah telah menetapkan Standar Nasional Pendidikan (SNP) yang meliputi Standar Kompetensi Lulusan; Standar Isi; Standar Proses; Standar Pendidikan dan Tenaga Kependidikan; Standar Sarana dan Prasarana; Standar Pengelolaan; Standar Pembiayaan Pendidikan; serta Standar Penilaian Pendidikan; guna menjaga mutu dan kualitas pendidikan di Indonesia

$$
\text { Zain dan Prayoga (2015) dalam }
$$
penelitiannya menjelaskan bahwa faktor dominan yang membentuk mutu pendidikan jenjang Sekolah Dasar dan Menengah di Kabupaten Sidoarjo pada tahun 2013 hingga 2014 adalah Standar Pelayanan dan Standar Kompetensi Lulusan. Penelitian tersebut menjelaskan bahwa mutu pendidikan dapat diukur menggunakan lebih dari 50 indikator dan berbentuk multivariat. Salah satu metode pengelompokan yang sesuai untuk data multivariat adalah Modeling Based Cluster. Metode ini merupakan metode pengelompokan berdasarkan model probabilitas yang digunakan untuk mengidentifikasi suatu kelompok pada populasi berdasarkan distribusi probabilitas dan keseluruhan populasi dimodelkan sebagai distribusi finite mixture.

Akhyar (2017) pada penelitian sebelumnya telah menggunakan Model Based Clustering untuk mengelompokan Kabupaten/Kota di Jawa Timur berdasarkan indikator pembangunan ekonomi pada tahun 2011 - 2015. Penelitian tersebut menghasilkan 3 kelompok wilayah dengan tingkat pembangunan ekonomi yang berbeda pada masing - masing kelompok, pengelompokan tersebut bersifat konsisten dan tidak mengalami perubahan selama tahun 2011 hingga 2013. Adapun pada tahun 2014 dan 2015 mengalami perubahan pengelompokan menjadi 2 cluster optimum.

Agustini (2015) juga melakukan penelitian dengan metode yang sama mengenai pengelompokan provinsi berdasarkan indikator pasar tenaga kerja tahun 2012 - 2015. Berbeda dengan penelitian Akhyar (2017), penelitian ini membagi data menjadi beberapa subset sehingga tiap subset memiliki indikator yang berbeda. Hasil penelitian tersebut menyatakan bahwa lebih dari 80 persen provinsi di Indonesia konsisten berada dalam kelompok 1, yaitu kelompok dengan karakteristik penduduknya bekerja dengan status berusaha sendiri atau dibantu buruh tidak dibayar. Serta diperoleh kesimpulan 
bahwa Papua teridentifikasi sebagai provinsi dengan persentase pekerja rentan dan persentase pekerja sektor informal tertinggi di Indonesia.

Bouveyron \& Brunet (2014) menerangkan bahwa metode ini dianggap lebih baik daripada metode cluster yang umum. Pengukuran kemiripan antar objek melalui ukuran jarak akan sangat sulit jika kondisi objek yang ada saling tumpang tindih. Mc Lachlan \& Peel (2000) menyatakan asumsi mixture berdistribusi $t$ multivariat mampu menghasilkan pengelompokan yang lebih robust dalam mengatasi outlier pada estimasi parameter. Keberadaan outlier menyebabkan variansi data menjadi besar, interval data menjadi lebar, serta nilai mean tidak dapat menunjukan nilai yang sebenarnya (bias).

\section{METODE PENELITIAN}

Penelitian ini menggunakan data sekunder mengenai indikator mutu pendidikan berdasarkan Standar Nasional Pendidikan (SNP) yaitu standar kompetensi lulusan, standar sarana prasarana, dan standar kompetensi pendidik dan tenaga kependidikan. Data diambil dari website Kemendikbud (Data Neraca Pendidikan dan Data Pokok Pendidikan) Tahun 2016 sampai 2018. Unit analisis yang digunakan dalam penelitian ini sebanyak 34 provinsi

Terdapat dua jenis variabel yang digunakan dalam penelitian ini, yaitu, variabel jenis akreditasi yang menjelaskan kualitas sekolah berdasarkan penilaian BAN-S/M, sedangkan variabel indikator pendidikan digunakan untuk mengukur kualitas pendidikan di tiap Provinsi tersebut. Rincian variabel dijelaskan dalam tabel berikut.

Tabel 2.1 Variabel Penelitian

\begin{tabular}{|c|l|}
\hline Variabel & \multicolumn{1}{|c|}{ Kategori } \\
\hline \multirow{2}{*}{$\begin{array}{c}\text { Jenis } \\
\text { Akreditasi } \\
\text { Sekolah }\end{array}$} & Sekolah terakreditasi A \\
\cline { 2 - 2 } & Sekolah terakreditasi B \\
\cline { 2 - 2 } & Sekolah terakreditasi C \\
\cline { 2 - 2 } & Sekolah belum terakreditasi \\
\hline
\end{tabular}

\section{Definisi Operasional:}

a. Terakreditasi A merupakan sekolah dengan kisaran nilai 91 - 100

b. Terakreditasi B merupakan sekolah dengan kisaran nilai 80 - 90

c. Terakreditasi $\mathrm{C}$ merupakan sekolah dengan kisaran nilai $70-79$

d. Belum Terakreditasi merupakan sekolah dengan kisaran nilai $0-69$

\begin{tabular}{|c|c|}
\hline Indikator & Variabel Indikator \\
\hline \multirow{3}{*}{ Standar PTK } & $\begin{array}{l}\text { Persentase guru berijazah } \geq \\
\text { D4/S1 }\left(X_{1}\right)\end{array}$ \\
\hline & $\begin{array}{l}\text { Persentase guru bersertifikasi } \\
\left(\mathrm{X}_{2}\right)\end{array}$ \\
\hline & $\begin{array}{l}\text { Persentase tenaga kependidikan } \\
\text { lulusan } \geq \mathrm{SM}\left(\mathrm{X}_{3}\right)\end{array}$ \\
\hline \multirow{4}{*}{$\begin{array}{l}\text { Sarana dan } \\
\text { Prasarana }\end{array}$} & $\begin{array}{l}\text { Persentase ruang kelas dengan } \\
\text { kondisi baik }\left(\mathrm{X}_{4}\right)\end{array}$ \\
\hline & $\begin{array}{l}\text { Persentase Perpustakaan dengan } \\
\text { kondisi baik }\left(\mathrm{X}_{5}\right)\end{array}$ \\
\hline & $\begin{array}{l}\text { Persentase Laboratorium dengan } \\
\text { kondisi baik }\left(\mathrm{X}_{6}\right)\end{array}$ \\
\hline & $\begin{array}{l}\text { Persentase ruang UKS dengan } \\
\text { kondisi baik }\left(\mathrm{X}_{7}\right)\end{array}$ \\
\hline \multirow{3}{*}{ Standar Proses } & $\begin{array}{l}\text { Rasio rombel dan jumlah peserta } \\
\text { didik }\left(\mathrm{X}_{8}\right)\end{array}$ \\
\hline & $\begin{array}{l}\text { Rata - rata nilai Uji Kompetensi } \\
\text { Guru }\left(\mathrm{X}_{9}\right)\end{array}$ \\
\hline & $\begin{array}{l}\text { Persentase peserta didik yang } \\
\text { mengakses internet }\left(\mathrm{X}_{10}\right)\end{array}$ \\
\hline $\begin{array}{l}\text { Standar } \\
\text { Kompetensi } \\
\text { Lulusan }\end{array}$ & Rata - rata nilai UN $\left(\mathrm{X}_{11}\right)$ \\
\hline \multirow{2}{*}{$\begin{array}{l}\text { Indikator } \\
\text { pendidikan } \\
\text { lainnya }\end{array}$} & $\begin{array}{l}\text { Persentase peserta didik putus } \\
\text { sekolah }\left(\mathrm{X}_{12}\right)\end{array}$ \\
\hline & $\begin{array}{l}\text { Persentase peserta didik } \\
\text { mengulang }\left(\mathrm{X}_{13}\right)\end{array}$ \\
\hline
\end{tabular}

Tabel 2.2 Variabel Indikator Mutu Pendidikan

Selanjutnya adalah menentukan subset data yang berasal dari kombinasi variabel penelitian. Struktur subset dibentuk berdasarkan bagan indikator yang disusun oleh Kementerian Pendidikan dan Kebudayaan (Kemendikbud) dalam bukunya yang berjudul "Indikator Mutu dalam Penjaminan Mutu Pendidikan Dasar dan Menengah" menjelaskan bahwa mutu pendidikan disusun oleh tiga komponen meliputi input, proses dan output. Serta beberapa variabel dari penelitian sebelumnya yang disesuaikan dengan analisis penelitian ini. Subset data yang terbentuk akan menjadi dasar pengelompokan 34 provinsi sebagaimana yang ditunjukan dalam tabel berikut ini.

Tabel 2.3 Subset Indikator Mutu Pendidikan 
Tiga subset yang terbentuk akan dibedakan menjadi 3 periode waktu, yaitu tahun 2016 sampi 2018. Sehingga menghasilkan struktur data sebgai berikut.

Tabel 2.4 Struktur Data

\begin{tabular}{|c|c|c|c|c|}
\hline \multirow{2}{*}{ Sub. } & \multirow{2}{*}{ Prov. } & \multicolumn{3}{|c|}{ Tahun } \\
\hline & & 2016 & 2017 & 2018 \\
\hline \multirow{3}{*}{$\begin{array}{c}S_{I_{-} I n} \\
\text { put.P } \\
T K\end{array}$} & JK & $\begin{array}{c}\mathrm{S}_{1} ; \mathrm{JK} \\
2016\end{array}$ & $\begin{array}{c}\mathrm{S}_{1} ; \mathrm{JK} \\
2017\end{array}$ & $\begin{array}{c}\mathrm{S}_{1} ; \mathrm{JK} ; \\
2018\end{array}$ \\
\hline & : & : & : & : \\
\hline & PB & $\begin{array}{c}\mathrm{S}_{1} ; \mathrm{PB} \\
2016\end{array}$ & $\begin{array}{c}\mathrm{S}_{1} ; \mathrm{PB} ; \\
2017\end{array}$ & $\begin{array}{c}\mathrm{S}_{1} ; \mathrm{PB} ; \\
2018\end{array}$ \\
\hline \multirow{3}{*}{$\begin{array}{c}S_{I_{-} I n} \\
\text { put.Sa } \\
\text { rpras }\end{array}$} & $\mathrm{JK}$ & $\begin{array}{c}\mathrm{S}_{1} ; \mathrm{JK} \\
2016\end{array}$ & $\begin{array}{c}\mathrm{S}_{1} ; \mathrm{JK} \\
2017\end{array}$ & $\begin{array}{c}\mathrm{S}_{1} ; \mathrm{JK} ; \\
2018\end{array}$ \\
\hline & : & : & : & : \\
\hline & PB & $\begin{array}{c}\mathrm{S}_{1} ; \mathrm{PB} \\
2016\end{array}$ & $\begin{array}{c}\mathrm{S}_{1} ; \mathrm{PB} \\
2017\end{array}$ & $\begin{array}{c}\mathrm{S}_{1} ; \mathrm{PB} \\
2018\end{array}$ \\
\hline \multirow{3}{*}{$S_{2}$} & JK & $\begin{array}{c}\mathrm{S}_{2} ; \mathrm{JK} ; \\
2016\end{array}$ & $\begin{array}{c}\mathrm{S}_{2} ; \mathrm{JK} \\
2017\end{array}$ & $\begin{array}{c}\mathrm{S}_{2} ; \mathrm{JK} ; \\
2018\end{array}$ \\
\hline & : & : & : & : \\
\hline & PB & $\begin{array}{c}\mathrm{S}_{2} ; \mathrm{PB} \\
2016\end{array}$ & $\begin{array}{c}\mathrm{S}_{2} ; \mathrm{PB} \\
2017\end{array}$ & $\begin{array}{c}\mathrm{S}_{2} ; \mathrm{PB} ; \\
2018\end{array}$ \\
\hline \multirow{3}{*}{$S_{3}$} & JK & $\begin{array}{c}\mathrm{S}_{3} ; \mathrm{JK} ; \\
2016\end{array}$ & $\begin{array}{c}\mathrm{S}_{3} ; \mathrm{JK} ; \\
2017\end{array}$ & $\begin{array}{c}\mathrm{S}_{3} ; \mathrm{JK} ; \\
2018\end{array}$ \\
\hline & : & $:$ & : & : \\
\hline & PB & $\begin{array}{c}\mathrm{S}_{3} ; \mathrm{PB} \\
2016\end{array}$ & $\begin{array}{c}\mathrm{S}_{3} ; \mathrm{PB} \\
2017\end{array}$ & $\begin{array}{c}\mathrm{S}_{3} ; \mathrm{PB} ; \\
2018\end{array}$ \\
\hline
\end{tabular}

Berdasarkan rumusan masalah yang diangkat dalam penelitian ini, maka diperoleh langkah - langkah analisis yang terangkum sebagai berikut.

1. Mendeskripsikan wilayah di Indonesia berdasarkan peringkat akreditasi pada satuan pendidikan (jenjang sekolah menengah pertama) tahun 2016 - 2018 menggunakan Arc View.

2. Melakukan pemeriksaan outlier multivariat pada data indikator - indikator mutu pendidikan menggunakan plot jarak Mahalanobis terhadap jarak Robust menggunakan fungsi distance-distance plot (dd plot).

3. Melakukan pengelompokan wilayah menggunakan metode Model Based Clustering.

4. Menentukan model terbaik dan jumlah kelompok optimum yang terbentuk melaui nilai ICL terbesar.

5. Menguji perbedaan rata - rata antar kelompok menggunakan Manova.

6. Melakukan interpretasi dan menarik kesimpulan dari hasil analisis.

\section{HASIL DAN PEMBAHASAN}

\begin{tabular}{|c|c|}
\hline Subset & Variabel \\
\hline $\mathrm{S}_{1 \_ \text {Input.PTK }}$ & $\mathrm{X}_{1}, \mathrm{X}_{2}, \mathrm{X}_{3}$ \\
\hline $\mathrm{S}_{1}$ Input.Sarpras & $\mathrm{X}_{4}, \mathrm{X}_{5}, \mathrm{X}_{6}, \mathrm{X}_{7}$ \\
\hline $\mathrm{S}_{1 \_ \text {Proses }}$ & $\mathrm{X}_{8}, \mathrm{X}_{9}, \mathrm{X}_{10}$ \\
\hline $\mathrm{S}_{1}$ Output & $\mathrm{X}_{11}, \mathrm{X}_{12}$ dan $\mathrm{X}_{13}$ \\
\hline
\end{tabular}

3.1 Karakteristik Provinsi Di Indonesia Berdasarkan Akreditasi

Predikat akreditasi diberikan untuk mengukur kinerja sekolah sebagai alat pembinaan, pengembangan, dan peningkatan mutu serta penentuan tingkat kelayakan sekolah dalam menyelenggarakan pelayanan pendidikan. Sekolah Menengah Pertama (SMP) merupakan pendidikan dasar yang harus terpenuhi, maka mutu pendidikan yang terukur melalui predikat akreditasi sekolah adalah minimal B.

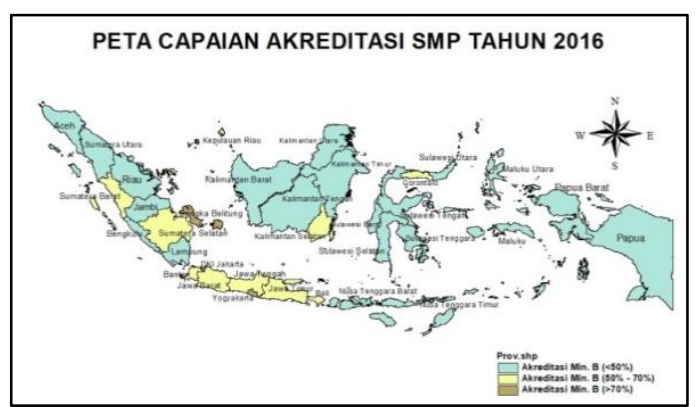

Gambar 3.1 Capaian Akreditasi SMP Tahun 2016

Gambar 3.1 menunjukan capaian akreditasi sekolah menengah pertama dari 34 provinsi di Indonesia. Wilayah dengan warna coklat merupakan wilayah yang memiliki sekolah terakreditasi minimal B mendekati 100\%, meliputi DKI Jakarta (73,2\%), Kepulauan Bangka Belitung $(84,4 \%)$, dan D.I. Yogyakarta $(96,8 \%)$. Warna kuning menggambarkan wilayah dengan capaian akreditasi minimal B kisaran $50 \%$ hingga $70 \%$ sebanyak 13 provinsi yaitu Gorontalo (51,3\%), Kepulauan Riau (59,8\%), Sumatera Selatan (54,6\%), Jawa Tengah $(68,6 \%)$, Banten $(56,2 \%)$, Jawa Timur $(52,7 \%)$, Jawa Barat (65,2\%), Kalimantan Selatan $(69,2 \%)$, Sumatera Barat $(67,2 \%)$ dan Bali $(55,5 \%)$. Sedangkan sisanya sebanyak 21 provinsi masih jauh dari target nasional pendidikan. Wilayah ini digambarkan dengan warna biru, yaitu capaian akreditasi min. B berada dibawah $50 \%$. Provinsi dengan capaian terendah dibawah $20 \%$ adalah Sulawesi Tengah $(13,8 \%)$, Maluku Utara $(10,8 \%)$ dan Nusa Tenggara Timur $(12,1 \%)$. 


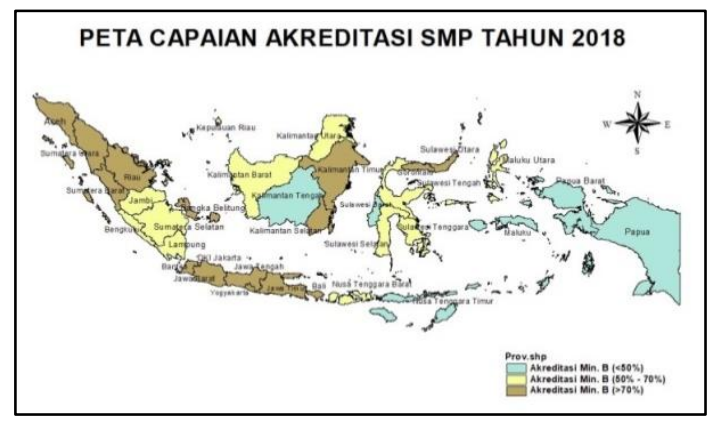

Gambar 3.2 Capaian Akreditasi SMP Tahun 2017

Jika di tahun sebelumnya warna biru mendominasi wilayah Indonesia, yang artinya akreditasi sekolah menengah pertama masih jauh dari target nasional. Pada tahun 2017 capaian akreditasi mengalami peningkatan di beberapa provinsi. Khususnya di Provinsi Aceh dan Kalimantan Timur. Aceh mampu mengalami peningkatan yang signifikan dari angka 36\% di tahun 2016 menjadi 74,3\% di tahun 2017. Angka tersebut mengalami peningkatan dua kali lipat untuk sekolah dengan Akreditasi A maupun B, sedangkan Kalimantan Timur meningkat dari $25,5 \%$ menjadi $74,2 \%$.

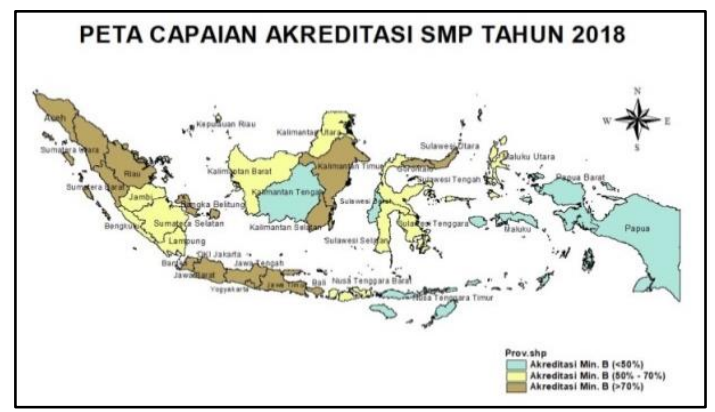

Gambar 3.3 Capaian Akreditasi SMP Tahun 2018

Capaian akreditasi minimal B mendekati $100 \%$ pada sekolah menengah pertama untuk tahun 2018 didominasi oleh wilayah Jawa, dengan capaian tertinggi di provinsi D.I. Yogyakarta $(95,66 \%)$ dengan komposisi sekolah terakreditasi A $(72,6 \%)$ dan terakreditasi B $(23,06 \%)$. Wilayah Sumatera termasuk dalam kategori mengalami peningkatan yang signifikan dibandingkan 2 tahun sebelumnya. Adapun wilayah yang belum mengalami peningkatan mutu pendidikan secara signifikan selama 3 tahun terakhir adalah Papua, Papua Barat, Kalimantan Tengah dan Nusa Tenggara Timur. Wilayah - wilayah tersebut mengalamai peningkatan tidak lebih dari $10 \%$ tiap tahunnya.

Sebagaimana yang telah dijelaskan dalam bab sebelumnya bahwa penelitian ini membagi objek pengamatan ke dalam 3 subset, yaitu Subset 1 (indikator input yang mencakup Standar PTK dan Standar Sarpras), Subset 2 (indikator proses yang mengukur aktivitas belajar - mengajar oleh peserta didik maupun pendidiknya ) dan Subset 3 (Indikator Output yang mengukur lulusan). Tahapan - tahapan analisis untuk mendapatkan hasil pengelompokan terbaik adalah sebagai berikut.

\subsection{Pemeriksaan Outlier Multivariat}

Pendeteksian outlier pada data indikator mutu pendidikan dilakukan untuk melihat adanya pencilan yang menyebabkan tidak terpenuhinya asumsi normal pada data penelitian, sehingga memiliki kecenderungan untuk diterapkan pada Model Based Clustering (MBC) finite mixture $t$ multivariat. Pengelompokan menggunakan metode MBC dianggap memiliki hasil yang lebih robust dari pada metode pengelompokan lainnya. Outlier multivariat dapat diketahui dengan menghitung jarak Mahalanobis dan jarak Robust dari objek pengamatan yang kemudian dibandingkan dengan nilai kuantil distribusi $\chi_{p ; 0.975}$ dengan jumlah variabel $(p)$ pada masing - masing subset.

Tabel 3.1 Hasil Pemeriksaan Outlier Pada $S_{1}$ Input.PTK

\begin{tabular}{|c|c|c|c|}
\hline \multirow{2}{*}{ Sub. } & Tahun & Outlier & $\begin{array}{c}\text { Provinsi } \\
\text { Terdeteksi } \\
\text { Outlier }\end{array}$ \\
\hline $\begin{array}{c}\text { S1_Input.PT } \\
\text { K }\end{array}$ & 2016 & & \\
\cline { 2 - 2 } & 2017 & 3 & $\begin{array}{c}\text { DI Yogyakarta, } \\
\text { Sulawesi Utara, } \\
\text { Maluku }\end{array}$ \\
\cline { 2 - 2 } & & \\
\hline
\end{tabular}

Tabel 3.1 menunjukan subset data input PTK mengandung nilai outlier di tiga provinsi yang sama selama 2016 - 2018, yaitu DI Yogyakarta, Sulawesi Utara dan Maluku. Subset ini menjelaskan kualifikasi Pendidik dan Tenaga Kependidikan yang ditunjukan oleh persentase guru berijazah min. S1 $\left(\mathrm{X}_{1}\right)$, persentase guru bersertifikasi $\left(\mathrm{X}_{2}\right)$ dan persentase lulusan tendik $\geq$ SMA $\left(\mathrm{X}_{3}\right)$. Ketiga provinsi tersebut memiliki capaian kualifikasi tendik berpendidikan $\geq$ SMA paling rendah dari 34 provinsi. Persentase tendidik lulusan $\geq$ SMA $\left(\mathrm{X}_{3}\right)$ DI Yogyakarta berada di kisaran $25 \%$ - $28 \%$ selama tiga tahun, Sulawesi Utara mencapai 19,8\% - 23,8\% dan persentase capaian di Maluku mencapai 17,8 $21,8 \%$ tiap tahunnya.

Tabel 3.2 Hasil Pemeriksaan Outlier Pada $S_{1 \_}$Input.Sarpras 


\begin{tabular}{|c|c|c|c|}
\hline Subset & Tahun & Outlier & $\begin{array}{c}\text { Provinsi } \\
\text { Terdeteksi } \\
\text { Outlier }\end{array}$ \\
\hline \multirow{7}{*}{ Output } & 2016 & 3 & $\begin{array}{c}\text { Nusa Tenggara } \\
\text { Timur, Papua, } \\
\text { Papua Barat }\end{array}$ \\
\cline { 2 - 4 } & 2017 & 3 & $\begin{array}{c}\text { Bali, Papua, } \\
\text { Papua Barat }\end{array}$ \\
\cline { 2 - 4 } & 2018 & 3 & $\begin{array}{c}\text { Sumatera Barat, } \\
\text { Papua, Papua } \\
\text { Barat }\end{array}$ \\
\hline
\end{tabular}

Tabel 3.2 menunjukan pendeteksian outlier pada subset data input mutu pendidikan yang tersusun atas variabel sarana prasarana sekolah. Dapat diketahui bahwa hasil pemeriksaa oulier pada $\mathrm{S}_{1}$ Input.Sarpras memuat outlier di titik yang berbeda-beda selama tiga tahun. DKI Jakarta menjadi wilayah memuat nilai ekstrim tertinggi di antara 34 provinsi selama 2016 -

\begin{tabular}{|c|c|c|c|}
\hline Subset & Tahun & Outlier & $\begin{array}{c}\text { Provinsi } \\
\text { Terdeteksi } \\
\text { Outlier }\end{array}$ \\
\hline \multirow{3}{*}{ Proses } & 2016 & 1 & DI Yogyakarta \\
\cline { 2 - 4 } & 2017 & 1 & DI Yogyakarta \\
\cline { 2 - 4 } & 2018 & 2 & $\begin{array}{c}\text { Nusa Tenggara } \\
\text { Timur, Papua }\end{array}$ \\
\hline
\end{tabular}

2018. Hal ini cenderung disebabkan oleh persentase fasilitas sekolah berkondisi baik di Jakarta berada mendekati 60\%. Kepulauan Bangka Belitung memiliki capaian tertinggi setelah DKI Jakarta untuk variabel persentase ruang UKS berkondisi baik, yaitu mencapai 57\%. Hal ini berbanding terbalik dengan Maluku Utara dan Sulawesi Barat, di mana terdapat fasilitas sekolah berstatus baik masih di bawah $20 \%$.

Tabel 3.3 Hasil Pemeriksaan Outlier Pada $\mathrm{S}_{2}$ Proses

Subset data proses $\left(\mathrm{S}_{2}\right.$ Proses $)$ merupakan kumpulan variabel yang mengukur proses pembelajaran yaitu rasio rombel dengan jumlah siswa $\operatorname{SMP}\left(\mathrm{X}_{8}\right)$, rata - rata nilai Uji Kompetensi Guru (UKG) $\left(\mathrm{X}_{9}\right)$ dan persentase siswa SMP yang mengakses internet $\left(\mathrm{X}_{10}\right)$. Tabel 4.2 menunjukan beberapa provinsi yang memuat outlier di tahun 2016 - 2018 yakni DI Yogyakarta, Nusa Tenggara Timur dan Papua. Di tahun 2016 -2017 DI Yogyakarta menjadi titik outlier dikarenakan berada pada nilai tertinggi untuk rata - rata nilai $\mathrm{UKG}\left(\mathrm{X}_{9}\right)$ dan kegiatan mengakses internet $\left(\mathrm{X}_{10}\right)$. Tahun 2018 titik outlier berada di Nusa Tenggara Timur dan Papua, hal ini cenderung disebabkan karena kedua wilayah tersebut mengalami penurunan

\begin{tabular}{|c|c|c|c|}
\hline Subset & Tahun & Outlier & $\begin{array}{c}\text { Provinsi } \\
\text { Terdeteksi } \\
\text { Outlier }\end{array}$ \\
\hline & 2016 & 2 & $\begin{array}{c}\text { DKI Jakarta, } \\
\text { Maluku Utara }\end{array}$ \\
\cline { 2 - 4 } S S_Input $_{\text {.Sarpras }}$ & 2017 & 3 & $\begin{array}{c}\text { DKI Jakarta, } \\
\text { Maluku Utara, } \\
\text { Sulawesi Barat }\end{array}$ \\
\cline { 2 - 4 } & 2018 & 3 & $\begin{array}{c}\text { DKI Jakarta, Kep. } \\
\text { Bangka Belitung, } \\
\text { Kalimantan Utara }\end{array}$ \\
\hline
\end{tabular}

yang signifikan selama tiga tahun terakhir pada penggunaan internet yakni berada pada kisaran tidak lebih dari $25 \%$.

Tabel 3.4 Hasil Pemeriksaan Outlier Pada $\mathrm{S}_{3}$ Output

Berdasarkan tabel 3.3 dapat diketahui bahwa wilayah yang memuat Outlier pada subset data output $\left(\mathrm{S}_{3} \_\right.$Output $)$cenderung sama selama 2016 - 2018. S3_Output mengukur kualitas lulusan melalui rata - rata nilai $\mathrm{UN}\left(\mathrm{X}_{11}\right)$, persentase siswa putus sekolah $\left(\mathrm{X}_{12}\right)$ dan persentase siswa mengulang tingkat $\left(\mathrm{X}_{13}\right)$. Provinsi Papua dan Papua Barat berada di titik outlier dikarenakan selama tiga tahun berturut turut persentase siswa mengulang terus meningkat hingga melebihi $1 \%$. Nusa Tenggara Timur cenderung dipengaruhi oleh persentase siswa mengulang yang mencapai angka tertinggi yakni lebih dari 1\%. Bali berada di titik outlier kerana dipengaruhi oleh persentase paling rendah untu siswa mengulang yakni mencapai $0,04 \%$ dan Sumatera Barat dipengaruhi oleh persentase siswa mengulang mendekati $1 \%$.

\subsection{Pengelompokan Provinsi di Indonesia Menggunakan Model Based Clustering Pengelompokan MBC mampu} mengidentifikasi setidaknya 28 model dengan jumlah kelompok maksimal 9 kelompok menggunakan package teigen software $R$. Adapun pemilihan kelompok optimum adalah dengan melihat nilai ICL terbesar. Pengelompokan tersebut akan menghasilkan struktur model sebagaimana dalam lampiran 1 .

\subsubsection{Pemilihan Kelompok Optimum dengan Kriteria Integrated Completed Likelihood (ICL) pada Subset Data Input (S1_Input)}

Pengelompokan provinsi berdasarkan indikator input mutu pendidikan ( $\mathrm{S}_{1}$ Input) pada tahun 2016 - 2018 menghasilkan maksimal 7 kelompok, sedangkan hasil iterasi di atas 7 kelompok menunjukan hasil infinite (Lampiran 11). 
Tabel 3.5 Hasil Iterasi MBC Berdasarkan Subset Input.PTK Tahun $2016-2018$

Berdasarkan tabel 3.5 Menunjukan model dan jumlah kelompok paling optimum yang dihasilkan selama 2016 - 2018 berdasarkan kriteria ICL terbesar menggunakan variabel kualifikasi PTK. Berdasarkan hasil pengelompokan $\mathrm{MBC}$, terpilihlah 2 kelompok $(\mathrm{G}=2)$ sebagai kelompok paling optimum dengan masing - masing nilai ICL yang diperoleh tiap tahunnya yaitu model CICU $(-197,831)$ untuk hasil pengelompokan tahun 2016, model CICC (208,925) di tahun 2017 dan pengelompokan di tahun 2018 menghasilkan model CUCC (200,31).

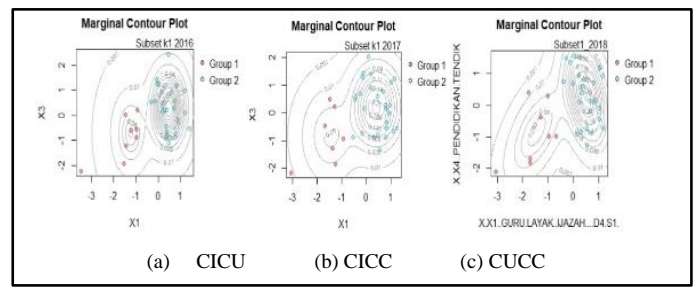

Gambar 3.4 Marginal Contour Plot ( $\mathrm{S}_{1}$ Input. PTK) Tahun $2016-2018$

Pemilihan variabel untuk visualisasi kontur dilakukan dengan mengombinasikan 2 dari 3 variabel paling berpengaruh. Kedua variabel tersebut adalah persentase guru berijazah min. S1 $\left(\mathrm{X}_{1}\right)$ dan persentase tenaga kependidikan min. SMA $\left(\mathrm{X}_{3}\right)$. Titik merah menunjukan anggota kelompok 1 dan dan titik biru menunjukan anggota kelompok 2.

Tahun 2016 menghasilkan model CICU dengan jumlah kelompok optumum sama dengan 2 ( $\mathrm{G}=2)$. Model CICU menunjukan model matriks kovarians dari kedua kelompok adalah $\sum_{g}=p_{k} \lambda B$ ( kedua kelompok memiliki volume dan bentuk yang hampir sama, dengan proporsi yang berbeda dan orientasi matriks berupa diagonal). Pengelompokan tahun 2017 menghasilkan model CICC dengan matriks kovarians adalah $\sum_{g}=p \lambda B$ (kedua kelompok menghasilkan volume, bentuk maupun proporsi yang mendekati sama dan orientasinya matriks berupa diagonal), sedangkan model cluster tahun 2018 adalah CUCC dengan matrik kovarians $\sum_{g}=p \lambda D_{k} A D_{k}{ }^{\prime} \quad$ (kedua kelompok memiliki volume, bentuk dan proporsi yang hampir sama namun orientasinya berbeda).

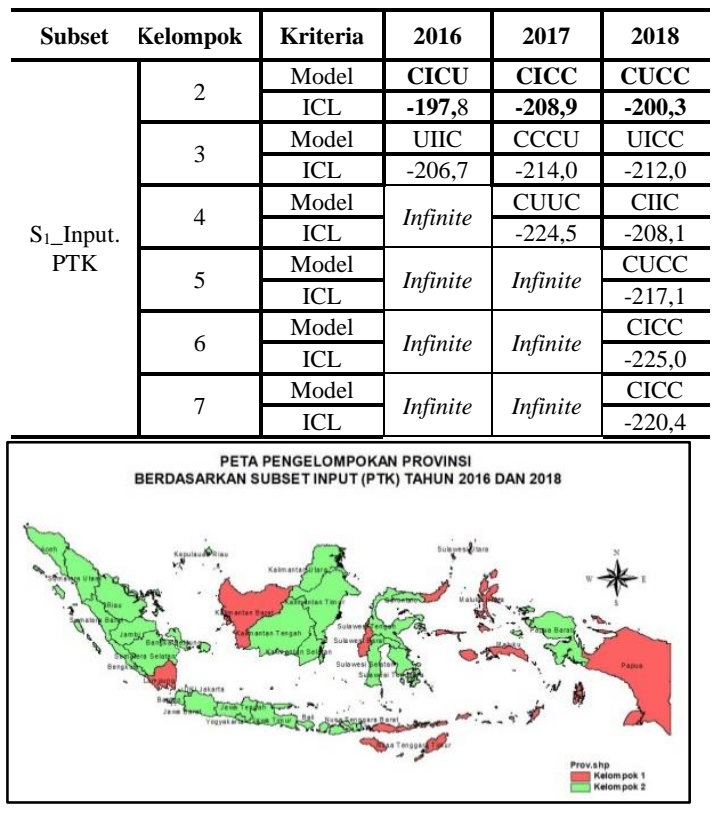

Gambar 3.5 Peta Pengelompokan Provinsi Berdasarkan Subset Input (PTK) Tahun 2016 \& 2018

Pengelompokan provinsi di Indonesia berdasarkan indikator input mutu pendidikan (variabel kualifikasi Pendidik dan Tenaga Kependidikan) tidak mengalami pergeseran yang berarti, susunan anggota dalam kelompok tetap sama. Gambar 4.5 menunjukan bahwa wilayah berwarna Merah merupakan Kelompok 1 yaitu, provinsi yang memiliki capaian indikator input mutu pendidikan yang lebin rendah. Kelompok 1 meliputi Kalimantan Barat, Lampung, Sulawesi Utara, Sulawesi Barat, Maluku Utara, Nusa Tenggara Timur, Papua dan Maluku. Adapun Kelompok 2 (wilayah yang berwarna Hijau) adalah provinsi dengan capaian indikator input mutu pendidikan yang paling signifikan di antara 34 provinsi.

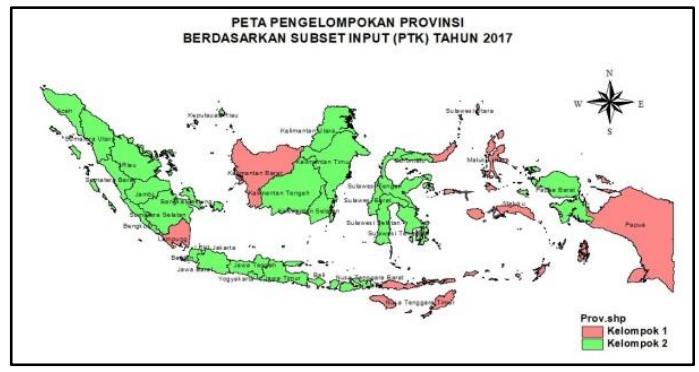

Gambar 3.6 Peta Pengelompokan Provinsi Berdasarkan Subset Input (PTK) Tahun 2017

Berdasarkan gambar 4.6 dapat diketahui bahwa terjadi pergeseran anggota kelompok di tahun 
2017, yaitu provinsi Sulawesi Barat. Tahun sebelumnya provinsi ini masuk dalam Kelompok 1 (wilayah dengan capaian kualifikasi PTK lebih rendah), begitu pula di tahun 2018. Namun di tahun ini, Sulaweso Barat masuk dalam Kelompok 2 (wilayah dengan capaian kualifikasi PTK yang signifikan).

Tabel 3.6 Hasil Iterasi MBC Berdasarkan Subset Input.Sarpras Tahun 2016 -2018

\begin{tabular}{|c|c|c|c|c|c|}
\hline Sub & $\begin{array}{c}\text { Kelomp } \\
\text { ok }\end{array}$ & Kriteria & 2016 & 2017 & 2018 \\
\hline \multirow{8}{*}{$\begin{array}{c}\mathrm{S}_{1} \_ \text {Input } \\
\cdot \\
\text { Sarpras }\end{array}$} & \multirow{2}{*}{2} & Model & UCCC & CUUC & $\mathrm{CCCC}$ \\
\hline & & ICL & $-154,1$ & $-147,9$ & $-142,1$ \\
\hline & \multirow{2}{*}{3} & Model & CCCC & CUUC & UCCC \\
\hline & & ICL & $-157,8$ & $-159,0$ & $-153,6$ \\
\hline & \multirow{2}{*}{4} & Model & CICC & CUCC & $\mathrm{CCCC}$ \\
\hline & & ICL & $-182,7$ & $-170,8$ & $-158,7$ \\
\hline & \multirow{2}{*}{5} & Model & \multirow{2}{*}{ Infinite } & \multirow{2}{*}{ Infinite } & CICC \\
\hline & & ICL & & & $-169,3$ \\
\hline
\end{tabular}

Berdasarkan tabel 3.6 dapat diketahui pengelompokan provinsi di Indonesia berdasarkan variabel sarpras tahun 2016 - 2018 menghasilkan dua kelompok $(\mathrm{G}=2)$ sebagai kelompok optimum menggunakan kriteria ICL terbesar. Model cluster tahun 2016 (UCCC) memiliki nilai ICL sebesar -164,072, model cluster tahun 2017 (CUUC) memiliki nilai ICL sebesar -147,973 dan model cluster tahun 2018 (CCCC) dengan nilai ICL sebesar -142,078

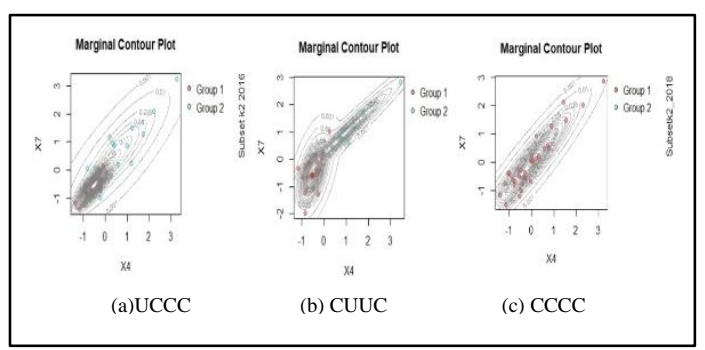

Gambar 3.7 Marginal Contour Plot ( $\mathrm{S}_{1} \_$Input. Sarpras) Tahun 2016 - 2018

Marginal contour plot untuk visualisasi pengelompokan provinsi di Indonesia berdasarkan indikator input Sarpras (S $\mathrm{S}_{1}$ Input.Sarpras) tahun 2016 - 2018 dapat dilihat pada gambar 3.7. Dua variabel yang terpilih sebagai kombinasi 2 variabel paling berpengaruh. Kedua variabel tersebut adalah persentase ruang kelas berkondisi baik $\left(\mathrm{X}_{4}\right)$ dan persentase ruang UKS berkondisi baik $\left(\mathrm{X}_{7}\right)$. Anggota Kelompok 1 ditunjukan dengan titik merah dan dan anggota Kelompok 2 ditunjukan dengan titik biru.

Model UCCC pada pengelompokan tahun 2016 menunjukan model matriks kovarians $\sum_{g}=p \lambda_{k} C$, yang artinya kedua kelompok memiliki bentuk, proporsi dan orientasi yang hampir sama, namun volume kedua kelompok berbeda. Pengelompokan tahun 2017 menghasilkan model CUUC dengan matriks kovarians adalah $\Sigma_{g}=p \lambda C_{k}$ kedua kelompok menghasilkan volume dan proporsi yang hampir sama, namun bentuk dan orientasinya berbeda, sedangkan model CCCC memiliki model matrik kovarians $\sum_{g}=p \lambda C$ (kedua kelompok memiliki volume, bentuk, proporsi dan orientasi yang hampir sama).

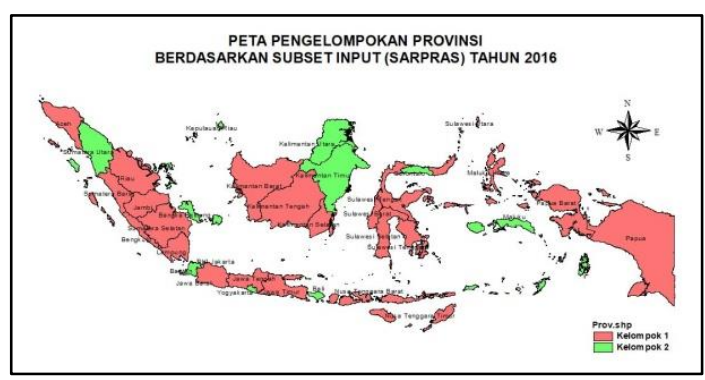

Gambar 3.8 Peta Pengelompokan Provinsi Berdasarkan Subset Input (Sarpras) Tahun 2016

Pengelompokan provinsi di Indonesia tahun 2016 berdasarkan indikator input mutu pendidikan (Sarpras) menghasilkan 2 kelompok. Gambar 3.8 menunjukan bahwa wilayah berwarna Merah merupakan Kelompok 1 yaitu, provinsi yang memiliki sekolah dengan kondisi sarana prasarana layak masih rendah, sedangkan Kelompok 2 (wilayah dengan fasilitas sekolah berstatus baik mengalami peningkatan). Kelompok 2 terdiri dari Kepulauan Bangka Belitung, Gorontalo, DKI Jakarta, Kepulauan Riau, Sumatera Utara, Banten, Yogyakarta, Kalimantan Utara, Kalimantan Timur, Maluku dan Bali.

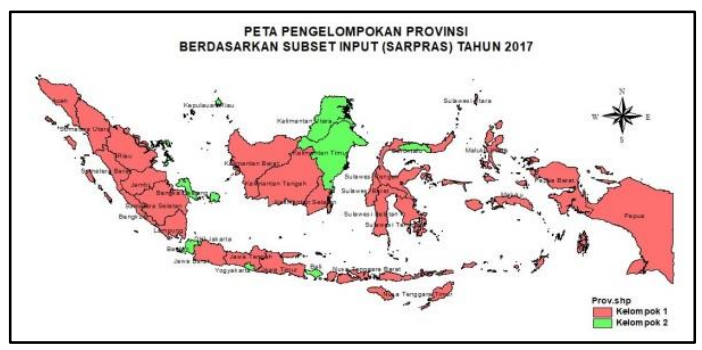

Gambar 3.9 Peta Pengelompokan Provinsi Berdasarkan Subset Input (Sarpras) Tahun 2017 
Pengelompokan provinsi di tahun 2017 menghasilkan 2 kelompok optimum, dengan kriteria Kelompok 1 adalah kelompok wilayah yang memiliki sarana - prasarana sekolah yang buruk dan Kelompok 2 adalah kelompok wilayah yang memiliki sarana - prasarana yang lebih baik. Provinsi yang termasuk dalam anggota Kelompok 2 meliputi Kepulauan Bangka Belitung, Gorontalo, DKI Jakarta, Kepulauan Riau, Banten, Yogyakarta, Kalimantan Utara, Kalimantan Timur dan Bali. Jika dibandingkan dengan tahun sebelumnya, terdapat 2 provinsi yang bergeser ke Kelompok 1 yaitu Sumatera Utara dan Maluku.

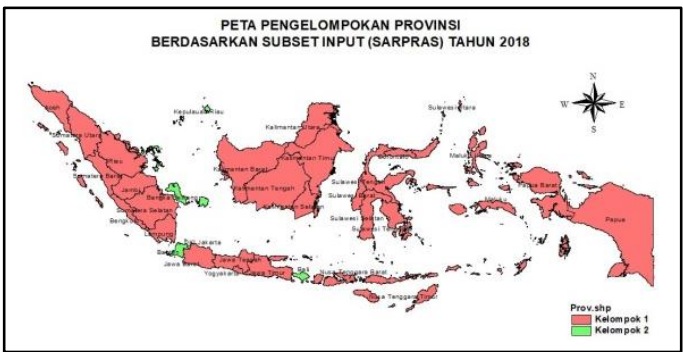

Gambar 3.10 Peta Pengelompokan Provinsi Berdasarkan Subset Input (Sarpras) Tahun 2018

Dapat diketahui pada gambar 3.10 peta pengelompokan provinsi di tahun 2018 didonimasi oleh warna Merah yang merupakan visualisasi dari Kelompok 1 (wilayah yang tergolong rendah pada kualitas sarana prasarana). Kelompok 2 merupakan wilayah dengan kondisi sarana - prasarana sekolah lebih baik. Provinsi yang masuk dalam Kelompok 2 meliputi Kepulauan Bangka Belitung, Kepulauan Riau, DKI Jakarta, Banten dan Bali.

\subsubsection{Pemilihan Kelompok Optimum dengan Kriteria Integrated Completed Likelihood (ICL) pada Subset Data Proses ( $\mathbf{S}_{2}$ Proses)}

Selanjutnya adalah pengelompokan berdasarkan indikator proses mutu pendidikan ( $\mathrm{S}_{2} \_$Proses) tahun 2016 - 2018. Pengelompokan MBC pada indikator $\mathrm{S}_{2}$ Proses mampu menghasilkan maksimal sebanyak 9 kelompok terbentuk (Lampiran 14).

Tabel 3.5 Hasil Iterasi MBC Berdasarkan Subset Proses Tahun 2016 -2018

\begin{tabular}{|c|c|c|c|c|c|}
\hline Sub. & Kel. & Kriteria & 2016 & 2017 & 2018 \\
\hline \multirow{6}{*}{ Proses } & \multirow{2}{*}{2} & Model & CIIC & CICC & UIIC \\
\hline & & ICL & $-217,3$ & $-216,7$ & $-204,5$ \\
\hline & \multirow{2}{*}{3} & Model & CICC & CIIC & CICC \\
\hline & & ICL & $-225,6$ & $-225,7$ & $-203,9$ \\
\hline & \multirow{2}{*}{4} & Model & \multirow{2}{*}{ Infinite } & CICC & CIIC \\
\hline & & ICL & & -234.8 & $-219,7$ \\
\hline
\end{tabular}

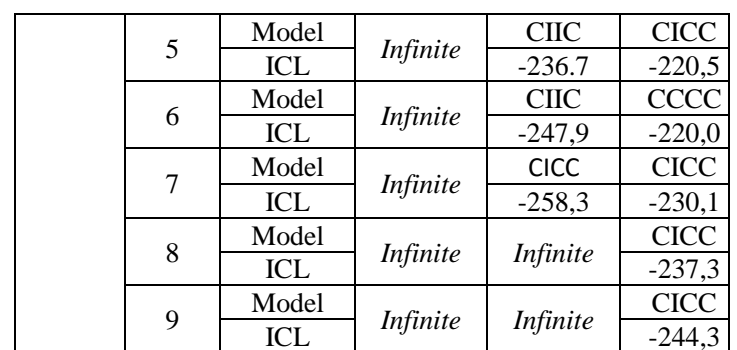

Tabel 3.5 merupakan hasil iterasi, model dan nilai ICL pada masing - masing kelompok. Pengelompokan di tahun 2016 menghasilkan maksimal 3 kelompok, hasil iterasi di atas 2 kelompok dianggap infinite. Pengelompokan di tahun 2017 menghasilkan hingga 7 kelompok dan tahun 2018 mampu menghasilkan maksimal 9 kelompok. Dapat diketahui pula di antara 3 kelompok yang dihasilkan dari proses iterasi tersebut, terpilih dua kelompok $(\mathrm{G}=2)$ sebagai kelompok optimum di tahun 2016 berdasarkan kriteria nilai ICL terbesar yaitu $-217,259$ dan diperoleh model cluster CIIC. Kelompok optimum di tahun 2017 adalah 2 kelompok $(\mathrm{G}=$ 2) dengan nilai ICL terbesar adalah -216,706 dengan model cluster CICC. Adapun kelompok optimum di tahun 2018 adalah tiga kelompok $(\mathrm{G}=3$ ) diperoleh nilai ICL terbesar yaitu $-203,948$ dengan model cluster CICC.

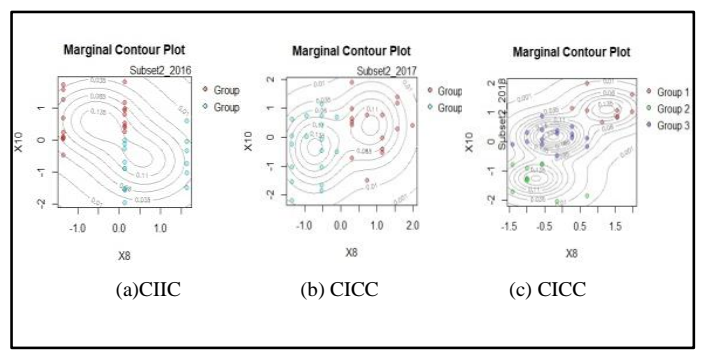

Gambar 3.11 Marginal Contour Plot $\left(\mathrm{S}_{2}\right.$ Proses) Tahun 2016 - 2018

Gambar 3.11 merupakan visualisasi marginal contour plot pada masing - masing periode pada data indikator proses mutu pendidikan ( $\mathrm{S}_{2}$ Proses) selama tahun 2016 - 2018. Variabel yang terpilih untuk visualisasi kontur adalah variabel yang paling berpengaruh. Kedua variabel tersebut adalah rasio jumlah siswa per rombel $\left(\mathrm{X}_{8}\right)$ dan persentase siswa mengakses internet $\left(\mathrm{X}_{10}\right)$. Model cluster CIIC tahun 2016 menunjukan model matriks kovarians $\sum_{g}=p \lambda I$, dapat diartikan bahwa 2 kelompok yang dihasikan dari pengelompokan MBC tahun 2016 memiliki volume dan proporsi yang hamper 
sama, berbentuk spcherical dan orientasi matriks tidak terdefinisi.

Tahun 2017 dan 2018 diperoleh model cluster yang sama yaitu CICC, yang menunjukan model matriks kovarians $\sum_{g}=p \lambda B$. Jika di tahun sebelumnya terbentuk 2 kelompok optimum, maka di tahun 2018 terbentuk kelompok optimum $(G=3)$. Berdasarkan plot tersebut dapat diartikan bahwa antar cluster memiliki bentuk, volume, fungsi kepadatan dan proporsi yang hampir sama, dengan orietasi berupa matriks diagonal.

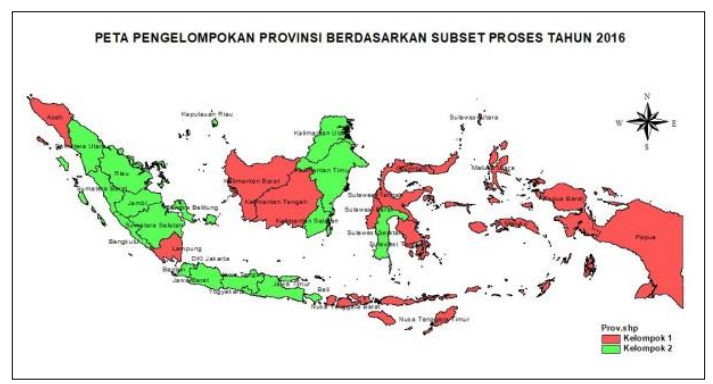

Gambar 3.12 Peta Pengelompokan Provinsi Berdasarkan Subset ProsesTahun 2016

Gambar 3.12 menunjukan bahwa Kelompok 1 (wilayah berwarna merah) terdiri dari provinsi yang memiliki capaian indikator proses mutu pendidikan yang rendah, seperti pada variabel presentase siswa yang mengakses internet $\left(\mathrm{X}_{10}\right)$ berada pada capaian di bawah $50 \%$. Begitu pula pada variabel rata - rata nilai UKG $\left(\mathrm{X}_{9}\right)$ pada kelompok 1 memiliki point yang lebih rendah daripada Kelompok 2 (wilayah berwarna hijau). Adapun variabel rasio jumlah siswa per rombel $\left(\mathrm{X}_{8}\right)$ memiliki angka yang sama dibeberapa provinsi. Wilayah berwarna hijau didominasi oleh pulau Jawa, Kalimantan serta beberapa provinsi di pulau Sumatera dan Sulawesi.

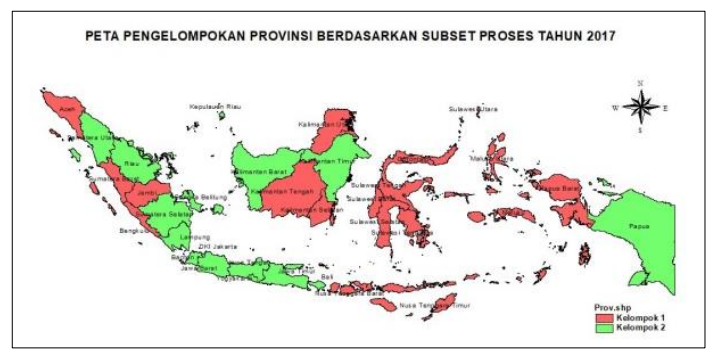

Gambar 3.13 Peta Pengelompokan Provinsi Berdasarkan Subset ProsesTahun 2017
Pengelompokan provinsi berdasarkan indikator proses mutu pendidikan ( $\mathrm{S}_{2}$ Proses) tahun 2017 pada gambar 4.13 menghasilkan 2 kelompok optimum, yaitu Kelompok 1 (wilayah bewarna merah) merupakan provinsi yang memiliki capaian indikator proses mutu pendidikan yang lebih rendah dari Kelompok 2. Terdapat beberapa provinsi yang mengalami pergeseran kelompok seperti Lampung, Kalimantan Barat dan Papua yang bergeser ke Kelompok 2 (wilayah dengan capaian terbaik). Hal ini dipengaruhi oleh rasio jumlah siswa per rombel $\left(\mathrm{X}_{8}\right)$ yang meningkat dibandingkan tahun sebelumnya. Adapun provinsi yang mengalami penurunan bergeser ke Kelompok 1 meliputi Kalimantan Selatan, Kalimantan Utara, Sulawesi Selatan, Sulawesi Barat, Jambi dan Bengkulu.

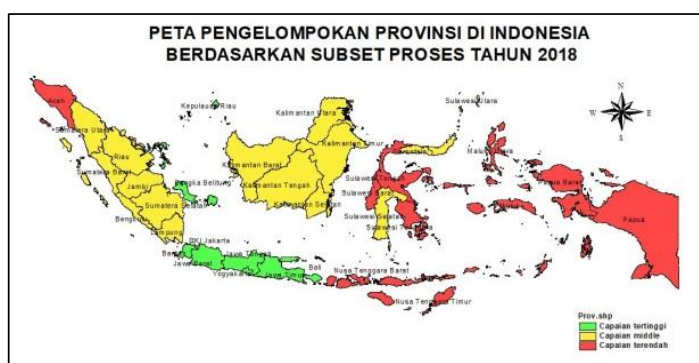

Gambar 3.14 Peta Pengelompokan Provinsi Berdasarkan Subset ProsesTahun 2018

Gambar 3.14 menunjukan pengelompokan provinsi di tahun 2018 yang terbagi menjadi 3 kelompok. Provinsi dengan capaian indikator tertinggi berada di Kelompok tertinggi (wilayah berwarna hijau), meliputi DKI Jakarta, Jawa Barat, Jawa Tengah, DI Yogyakarta, Jawa Timur, Bali, Banten, Kepulauan Bangka Belitung dan Kepulauan Riau. Wilayah berwarna kuning dijelaskan sebagai provinsi dengan kategori middle dalam capaian indikatornya. Wilayah berwarna merah didefinisikan sebagai kelompok terendah karena memiliki rasio jumlah perseta didik per rombel $\left(\mathrm{X}_{8}\right)$, rata - rata nilai $\mathrm{UKG}\left(\mathrm{X}_{9}\right)$ dan persentase siswa dalam mengakses internet $\left(\mathrm{X}_{10}\right)$ terendah di antara kelompok lainnya.

\subsubsection{Pemilihan Kelompok Optimum dengan Kriteria Integrated Completed Likelihood (ICL) pada Indikator

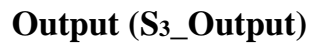

Pengelompokan berikutnya berdasarkan indikator output mutu pendidikan ( $\mathrm{S}_{3}$ Output) pada 34 provinsi di Indonesia menghasilkan 4 hingga 6 kelompok dari proses iterasi, sedangkan pembentukan jumlah kelompok lainnya menunjukan hasil infinite (Lampiran 23 -25). 
Tabel 3.6 Hasil Iterasi MBC Berdasarkan Subset Output

\begin{tabular}{|c|c|c|c|c|c|}
\hline \multicolumn{6}{|c|}{ Tahun $2016-2018$} \\
\hline Sub. & Kel. & Kriteria & 2016 & 2017 & 2018 \\
\hline \multirow{12}{*}{ Output } & \multirow{2}{*}{2} & Model & CUCC & UICC & CIUC \\
\hline & & ICL & $-209,74$ & $-199,22$ & $-191,18$ \\
\hline & \multirow{2}{*}{3} & Model & CIIC & $\mathrm{CICC}$ & $\mathrm{CICU}$ \\
\hline & & ICL & $-220,24$ & $-213,59$ & $-202,36$ \\
\hline & \multirow{2}{*}{4} & Model & \multirow{2}{*}{ Infinite } & $\mathrm{CCCC}$ & $\mathrm{CICC}$ \\
\hline & & ICL & & $-222,18$ & $-198,13$ \\
\hline & \multirow{2}{*}{5} & Model & \multirow{2}{*}{ Infinite } & $\mathrm{CCCC}$ & CICC \\
\hline & & ICL & & $-218,33$ & $-210,33$ \\
\hline & \multirow{2}{*}{6} & Model & \multirow{2}{*}{ Infinite } & CICC & CICC \\
\hline & & ICL & & $-235,02$ & $-220,17$ \\
\hline & \multirow{2}{*}{7} & Model & \multirow{2}{*}{ Infinite } & CICC & \multirow{2}{*}{ Infinite } \\
\hline & & ICL & & $-240,11$ & \\
\hline
\end{tabular}

Pengelompokan provinsi di Indonesia berdasarkan variabel output tahun 2016 - 2018 menunjukan bahwa dua kelompok $(\mathrm{G}=2)$ menjadi kelompok optimum yang terpilih dengan kriteria ICL terbesar. Tahun 2016 menghasilkan model CUCC dengan nilai ICL sebesar -209,743. Tahun 2017 menghasilkan model UICC dengan nilai ICL sebesar -199,221 dan model cluster tahun 2018 adalah CIUC dengan nilai ICL sebesar 191,184 .

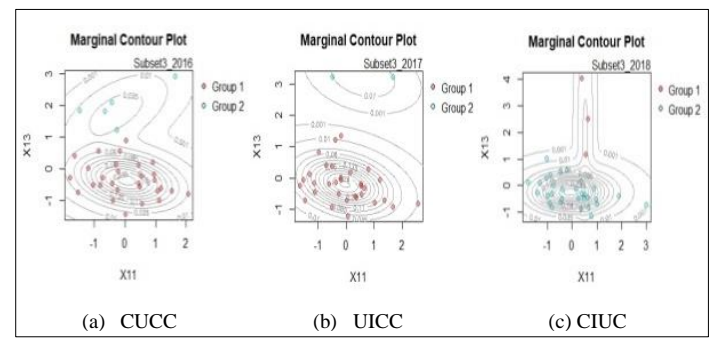

Gambar 3.15 Marginal Contour Plot ( $\mathrm{S}_{2}$ Output) Tahun $2016-2018$

Gambar 3.15 merupakan marginal contour plot yang terbentuk pada pengelompokan provinsi di Indonesia berdasarkan indikator input

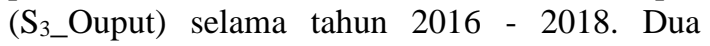
variabel terpilih dalam visualisasi kontur yaitu rata - rata nilai $\mathrm{UN}\left(\mathrm{X}_{11}\right)$ dan persentase siswa mengulang $\left(\mathrm{X}_{13}\right)$. Titik merah menunjukan anggota Kelompok 1 dan dan titik biru menunjukan anggota Kelompok 2. Plot tersebut menggambarkan model cluster CUCC di tahun 2016 dengan matrik kovarians $\sum_{g}=p \lambda D_{k} A D_{k}{ }^{\prime}$, yang artinya volume, bentuk dan proporsi antara dua kelompok hampir sama namun orientasinya berbeda.

Model yang diperoleh dari hasil pengelompokan provinsi di tahun 2017 adalah UICC dengan matriks kovarians $\sum_{g}=p \lambda_{k} B$, yang artinya kedua kelompok bentuk dan proporsi yang hampir sama namun volume nya berbeda. Sedangkan label I pada model menunjukan matriks ortogonal eigenvector membentuk matriks identitas.

Berbeda dengan tahun 2017, bentuk marginal contour plot pada tahun 2018 menggambarkan model cluster CIUC, dengan matriks kovarians yang diperoleh adalah $\sum_{g}=p \lambda B_{k} \quad$ (kedua kelompok mempunyai volume dan proporsi yang hampir sama, memiliki bentuk yang berbeda serta orientasi berbentuk matriks identitas).

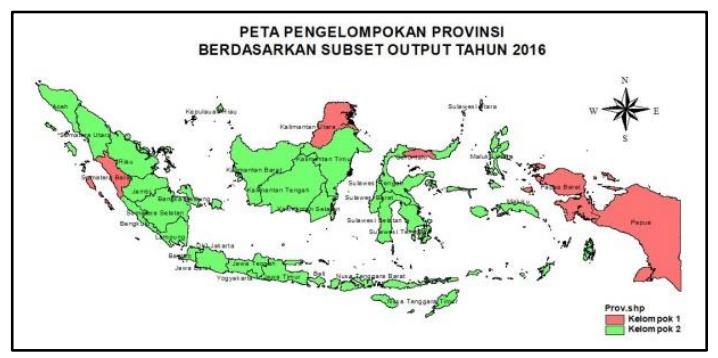

Gambar 3.16 Peta Pengelompokan Provinsi Berdasarkan Subset Output Tahun 2016

Gambar 3.16 merupakan pengelompokan provinsi berdasarkan indikator output mutu pendidikan tahun 2016. Kelompok 1 ditunjukan dengan wilayah berwarna Merah, yaitu provinsi dengan persentase siswa mengulang $\left(\mathrm{X}_{13}\right)$ tertinggi dibandingkan provinsi lainnya, angka tersebut mendekati $1 \%$. Kelompok 1 meliputi Papua, Papua Barat, Gorontalo, Sumatera Barat dan Kalimantan Utara. Sebaliknya Kelompok 2 ditunjukan dengan wilayah berwarna Hijau merupakan provinsi dengan persentase siswa mengulang lebih rendah.

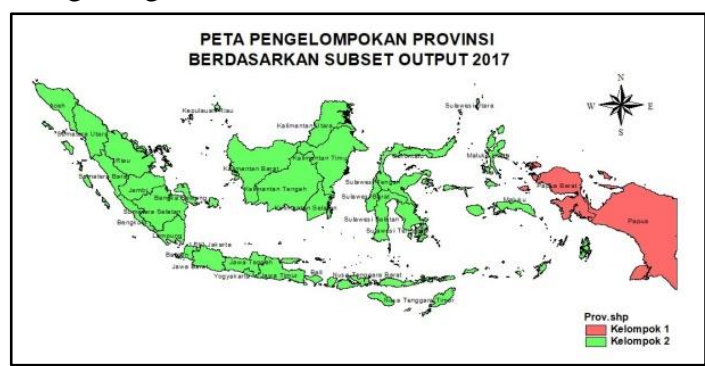

Gambar 3.17 Peta Pengelompokan Provinsi Berdasarkan Subset Output Tahun 2017

Apabila dibandingkan dengan tahun sebelumnya, terdapat perubahan warna pada provinsi Gorontalo, Sumatera Barat dan Kalimantan Utara. Berdasarkan gambar 3.17 ketiga provinsi tersebut bergeser masuk ke Kelompok 2, yaitu kelompok dengan persentase angka putus sekolah $\left(\mathrm{X}_{12}\right)$ dan persentase angka mengulang $\left(\mathrm{X}_{13}\right)$ yang lebih rendah. Adapun Kelompok 1 merupakan wilayah dengan capaian tertinggi untuk kasus putus sekolah dan 
mengulang, yaitu Papua dan Papua Barat. Ada begitu banyak faktor kemungkinan penyebab siswa putus sekolah diantaranya adalah keterbatasan ekonomi, fasilitas pendidikan serta minat belajar siswa yang rendah khususnya di daerah pedalaman.

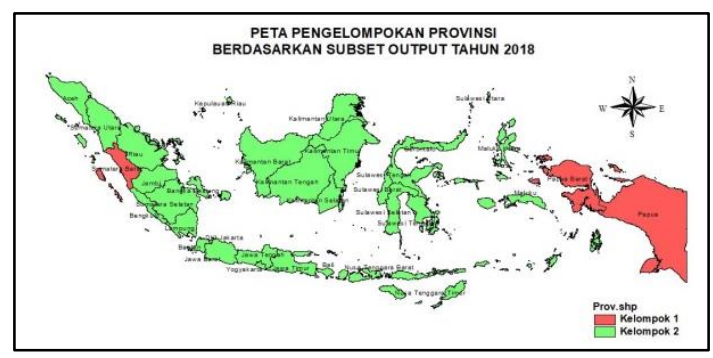

Gambar 3.18 Peta Pengelompokan Provinsi Berdasarkan Subset Output Tahun 2018

Hasil pengelompokan provinsi berdasarkan indikator output mutu pendidikan di tahun 2018 juga tidak mengalami perbedaan yang berarti. Kelompok 1 sebagai wilayah dengan persentase siswa putus sekolah $\left(\mathrm{X}_{12}\right)$ dan persentase angka mengulang $\left(\mathrm{X}_{13}\right)$ tertinggi, terdiri dari Sumatera Barat, Papua dan Papua Barat. Sedangkan kelompok lainnya berada pada Kelompok 2 (wilayah berwarna hijau).

\subsection{Uji Kesamaan Kelompok}

Uji kesamaan kelompok melalui uji Manova digunakan untuk melihat adanya perbedaan antar kelompok secara signifikan. Adapun hasil analisisnya dapat diketahui melalui tahapan sebagai berikut.

Hipotesis:

$H_{0}: \tau_{1}=\tau_{2}=0$ (tidak ada perbedaan antar kelompok)

$H_{1}: \tau_{1} \neq \tau_{2}($ Kelompok 1 berbeda dengan Kelompok 2)

Keputusan Tolak $H_{0}$ jika $p$-value lebih kecil dari $\alpha=0,05$. Penelitian ini akan membandingkan pengelompokan provinsi berdasarkan subset pada masing - masing tahunnya.

Tabel 3.7 Hasil Uji Manova
\begin{tabular}{|c|c|c|c|}
\hline Subset & $\begin{array}{c}\text { Wilk's } \\
\text { Lamda }\end{array}$ & F $_{\text {hitung }}$ & $\begin{array}{c}\boldsymbol{p} \text { - } \\
\text { value }\end{array}$ \\
\hline $\mathrm{S}_{1 \_ \text {Input.PTK (2016) }}$ & 0,26638 & 27,541 & 0,000 \\
\hline $\mathrm{S}_{1 \_ \text {Input.PTK (2017) }}$ & 0,29612 & 23,770 & 0,000 \\
\hline $\mathrm{S}_{1 \_ \text {Input.PTK (2018) }}$ & 0,22778 & 33,902 & 0,000 \\
\hline
\end{tabular}

Tabel 3.7 Hasil Uji Manova (Lanjutan)

\begin{tabular}{|l|c|c|c|}
\hline \multicolumn{1}{|c|}{ Subset } & $\begin{array}{c}\text { Wilk's } \\
\text { Lamda }\end{array}$ & F $_{\text {hitung }}$ & $\begin{array}{c}\boldsymbol{p} \text { - } \\
\text { value }\end{array}$ \\
\hline $\mathrm{S}_{1 \_ \text {Input.Sarpras (2016) }}$ & 0,34248 & 13,919 & 0,000 \\
\hline $\mathrm{S}_{1 \_ \text {Input.Sarpras (2017) }}$ & 0,29566 & 17,271 & 0,000 \\
\hline $\mathrm{S}_{1}$ Input.Sarpras (2018) & 0,34151 & 13,979 & 0,000 \\
\hline $\mathrm{S}_{2 \_ \text {Proses (2016) }}$ & 0,26609 & 27,581 & 0,000 \\
\hline
\end{tabular}

\begin{tabular}{|l|l|l|l|}
\hline $\mathrm{S}_{2 \_}$Proses (2017) & 0,24586 & 30,673 & 0,000 \\
\hline $\mathrm{S}_{2 \_}$Proses (2018) & 0,42172 & 13,712 & 0,000 \\
\hline $\mathrm{S}_{3 \_ \text {Output (2016) }}$ & 0,27892 & 25,852 & 0,000 \\
\hline $\mathrm{S}_{3 \_}$Output (2017) & 0,20404 & 39,011 & 0,000 \\
\hline $\mathrm{S}_{3 \_}$Output (2018) & 0,25860 & 28,670 & 0,000 \\
\hline
\end{tabular}

Berdasarkan hasil uji manova dapat diketahui statistik nilai Wilk's Lamda memiliki $p$ value lebih kecil dari $\alpha=0,05$ pada semua subset yang diuji. Sehingga keputusan yang diambil adalah tolak $H_{0}$ yang artinya terdapat perbedaan vektor mean antar kelompok pada masing masing subset data. Maka dapat disimpulkan bahwa metode MBC dapat diterapkan sebagai metode pengelompokan.

\section{KESIMPULAN DAN SARAN}

\subsection{Kesimpulan}

1. Selama tiga tahun terakhir (2016 - 2018) target capaian akreditasi min. B untuk SMP di Indonesia mengalami peningkatan secara signifikan hingga mendekati 100\%, kecuali di beberapa provinsi seperti Papua, Papua Barat, Kalimantan Tengah dan Nusa Tenggara Timur.

2. Hasil pemeriksaan outlier melalui $d d$-plot menunjukan titik outlier yang berbeda berdasarkan masing - masing indikator subsetnya. Nilai ekstrim pada subset data input $\left(S_{1}\right.$ Input) terletak di DKI Jakarta, Maluku dan Maluku Utara. Pada subset data proses ( $\mathrm{S}_{2} \_$Proses), nilai ekstrim didominasi oleh DI Yogyakarta. Sedangkan nilai ekstrim pada subset data output ( $\mathrm{S}_{3}$ Output) selalu didominasi oleh provinsi Papua dan Papua Barat.

3. Berdasarkan pengelompokan menggunakan 4 subset yang mengukur mutu pendidikan, yaitu kualifikasi PTK ( $\mathrm{S}_{1 \_}$Input.PTK), Sarpras ( $\mathrm{S}_{1} \_$Input.Sarpras), kegitan proses belajar - mengajar $\left(S_{2} \_\right.$Proses $)$dan output pendidikan ( $\mathrm{S}_{3}$ Output). Masing - masing subset kebanyakan menghasilkan 2 kelompok optimum tiap tahunnya, sehingga dapat disimpulkan beberapa hal:

a. Kualifikasi PTK (S1_Input.PTK): Kelompok optimum yang terbentuk adalah 2 kelompok $(G=2)$ dengan model cluster tiap tahunnya yaitu CICU untuk hasil pengelompokan tahun 2016, model CICC di tahun 2017 dan pengelompokan di tahun 2018 menghasilkan model CUCC. Kombinasi variabel yang paling berpengaruh adalah persentase guru berijazah min. S1 $\left(X_{1}\right)$ 
dan persentase lulusan tendik min. SMA $\left(\mathrm{X}_{3}\right)$.

b. Sarana prasarana sekolah (S1_Input. Sarpras): Kelompok optimum yang selama 2016 - 2018 adalah 2 kelompok $(\mathrm{G}=2)$. Model cluster yang diperoleh yaitu UCCC, model cluster tahun 2017 adalah CUUC, sedangkan model cluster tahun 2018 adalah CCCC. Variabel paling berpengaruh adalah persentase ruang kelas berkondisi baik $\left(\mathrm{X}_{4}\right)$ dan persentase ruang UKS berkondisi baik $\left(\mathrm{X}_{7}\right)$.

c. Subset Proses (S2_Proses): Pengelompokan tahun 2016 - 2017 menghasilkan 2 kelompok optimum $(\mathrm{G}=2)$, sedangkan tahun 2018 menghasilkan 3 kelompok $(\mathrm{G}=3)$. Kombinasi variabel yang terpilih adalah rasio jumlah siswa per rombel $\left(\mathrm{X}_{8}\right)$ dan persentase siswa mengakses internet $\left(\mathrm{X}_{10}\right)$. Model CIIC di tahun 2016, sedangkan pengelompokan tahun 2017 2018 menghasilkan model cluster yang sama yaitu CICC.

d. Subset Output (S3_Output): Menghasilkan 2 kelompok optimum $(\mathrm{G}=2)$ dengan model cluster yang terpilih adalah CUCC di tahun 2016, model UICC di tahun 2017 dan model cluster CIUC di tahun 2018. Variabel yang memberikan pengaruh adalah rata - rata nilai UN $\left(\mathrm{X}_{11}\right)$ dan persentase siswa mengulang $\left(\mathrm{X}_{13}\right)$.

4. Pengelompokan yang terbentuk berdasarkan subset input.PTK, subset input.Sarpras, subset proses dan subset output memiliki perbedaan antar kelompoknya, sehingga dapat disimpulkan bahwa Model Based Clastering bisa diterapkan pada data indikator mutu pendidikan di Indonesia.

5. Karakteristik kelompok pada masing masing subset yaitu:

a. Jika ditinjau dari kualifikasi PTK (S1_Input.PTK): Kelompok 2 menjadi kelompok terbaik untuk capaian variabel PTK selama 2016 - 2018. Seluruh provinsi di pulau Jawa serta sebagian wilayah (Sumatera, Kalimantan dan Sulawesi) menjadi wilayah yang paling konsisten berada di kelompok ini, sedangkan provinsi lainnya khususnya Papua, NTB dan NTB masih berada di capaian terendah (Kelompok 1). Perlu menjadi perhatian, mengingat jumlah guru yang berijazah min. S1 sudah mendekati $100 \%$ tiap tahunnya, namun yang terserap untuk mengikuti sertifikasi tidak melebihi 50\%. Selain itu tendik yang memiliki ijazah min. SMA masih sangat sedikit.

b. Subset input sarpras (S1_Input.Sarpras): Secara deskriptif terlihat amat berbeda secara karakteristik jika dilihat dari nilai mean antar kelompok. Provinsi di Indonesia yang memiliki sarana dan prasarana sekolah berkondisi baik masih di bawah $20 \%$. Kondisi ini juga mengalami penurunan dari tahun 2016 - 2018, dengan wilayah konsisten berada di Kelompok 2 (fasilitas sekolah terbaik) selama tiga tahun berturut - turut adalah DKI Jakarta, Banten, Bali dan Kepulauan Bangka Belitung.

c. Subset data proses (S2_Proses): Variabel yang paling memberikan perbedaan secara deskriptif antar kelompoknya adalah persentase siswa mengakses internet $\left(\mathrm{X}_{10}\right)$. Pulau Jawa merupakan wilayah yang paling konsisten berada di kelompok terbaik, sedangkan Papua, NTT, NTB dan beberapa wilayah Sulawesi lainnya berada di kelompok terendah.

d. Subset data output (S3_Output): Karaskteristik kelompok secara deskriptif berdasarkan subset data output ( $\mathrm{S}_{3} \_$Output) terlihat memiliki perbedaan pada variabel persentase siswa putus sekolah $\left(\mathrm{X}_{12}\right)$ dan variabel persentase siswa mengulang $\left(\mathrm{X}_{13}\right)$. Wilayah yang mengalami ketertinggalan mutu pendidikan berdasarkan kualitas lulusan selama tahun 2016 - 2018 ialah Papua dan Papua Barat. Keduanya berturut - turut masuk dalam Kelompok 1 (kelompok tertinggi kasus siswa putus sekolah dan siswa mengulang).

\subsection{Saran}

Faktor - faktor yang tidak terukur kemungkinan memberikan pengaruh yang lebih besar terhadap mutu pendidikan. Hal ini menjadi kelemahan dalam penelitian ini, sehingga diperlukan adanya kajian serta penelitian lain yang mendalam untuk menentukan variabel variabel yang lebih sesuai 


\section{DAFTAR PUSTAKA}

Badan Standar Nasional Pendidikan. (2006). Standar Nasional Pendidikan. Badan Standar Nasional Pendidikan: Jakarta

Biernacki, C., Celeux, G. \& Govaert, G. (2000). Assessing a Mixture Model for Clustering with the Integrated 52 Completed Likelihood. IEEE Trans. Pattern Anal. Mach. Intel. 719-725.

Bouveyron, C. \& Brunet-Saumard, C., (2014). Model-Based Clustering of High Dimensional Data: A Review. Computational Statistics and Data Analysis.

BPS. (2017). Indeks Integritas Ujian Nasional. Tersedia pada https://www.bps.go.id Diakses pada 5 November 2019

Branfield, J. D. \& Raftery, A. E. (1993) ModelBased Gaussian and Non-Gaussian Clustering. Biometrics, 49, 803-821.

Dempster, A.P., Laird,, N.M., and Rubin, D.B.. (1977). Maximum Likelihood from Incomplete Data via the EM Algorithm, Journal of the Royal Statistical Society. Series B (Methodological). Vol. 39, No. 1. (1977), pp. 1-38.

Hair, J. F., Black, W. C., Babin, B. J., \& et al. (2009). Multivariate Data Analysis (7th ed.). Upper Saddle River: Prentice Hall.

Handayani, Meni. (2018). Pencapaian Standar Nasional Pendidikan Berdasarkan Hasil Akreditasi SMA Di Provinsi DKI Jakarta. Balitbang Kemendikbud: Pusat Penelitian Kebijakan dan Kebudayaan)

Huber, P.J., (1973). Robust Estimation of a Location Parameter. The Annals of Mathematical Statistics, 35, 73-101.

Kemdikbud. (2017). Rumus Indikator Angka Partisipasi Kasar (APK). Tersedia pada http://apkapm.data.kemdikbud.go.id Diakses tanggal 5 November 2019

Konietschke, F., Bathke, A.C., Harrar, S.W. (2015). Parametric and Nonparametric Bootstrap Methods for General MANOVA, 292-293.

McLachlan, G. and Peel, D. (2000). Finite Mixture Models. Wiley Series in Probability and Statistics. John Wiley \& Sons, Inc.

Putra, Muslimin. (2019). Indeks Integritan Ujian Nasional. Yersedia pada https://www.academia.edu/24415670/Inte
gritas_Pelaksana_Ujian_Nasional.

Diakses pada 12 November 2019.

Satmoko.S. (1996). Faktor Pendidikan. Jakarta:

Direktorat Jenderal Pembinaan

Kelembagaan Agama Islam dan

Universitas Terbuka

Soedijarto. (2008). Landasan dan Arah Pendidikan Nasional Kita. Jakarta: PT. Kompas Media Nussantara.

Walpole, R.E. (2007). Pengantar Statistika. Edisi ke- $\quad 3$. Terjemahan Bambang Sumantri.Jakarta: PT. Gramedia Pustaka Utama.

Zain dan Prayoga. 2015. Analisis Faktor dan Pengelompokan Kecamatan Berdasarkan Indikator Mutu Pendidikan Jenjang Pendidikan Dasar di Kabupaten Sidoarjo. Surabaya: Institut Teknologi Sepuluh Nopember 